\title{
SPHKAP wt Allele
}

National Cancer Institute

\section{Source}

National Cancer Institute. SPHKAP wt Allele. NCI Thesaurus. Code C127886.

Human SPHKAP wild-type allele is located in the vicinity of 2 q36 and is approximately 202 $\mathrm{kb}$ in length. This allele, which encodes A-kinase anchor protein SPHKAP, plays a role in the regulation of protein kinase A-dependent signaling. 